\title{
VAN DE REDACTIE
}

In juli 1967 werd door de redactie een prijsvraag uitgeschreven met als onderwerp:

Het ontwerpen van een bedrijfsspel, dat betrekking heeft op de bedrijfseconomische problematiek van een onderneming en dat in het bijzonder geschikt is voor opneming in een opleidingsprogramma voor het hogere bedrijfskader en in het studieprogramma van het economisch hoger onderwijs.

De sluitingsdatum voor de inzendingen was gesteld op 1 september 1968 . In het november/december nummer van 1968 konden wij mededeling doen dat dertien inzendingen uit verschillende landen ons hadden bereikt. Deze landen waren Nederland, Engeland, U.S.A., Zuid-Afrika, Italië en Rusland. De commissie van beoordeling bestond uit de heren Prof. Dr. A.I. Diepenhorst, Prof. Dr. H.A. Hutte en Prof. Drs. A.H. Hulshof. Deze commissie rapporteerde in het nummer van mei 1969 dat AWICO, de inzending van de heren Drs. W. A. Nijenhuis, Drs. S. de Vries en Drs. A. Bosman, was bekroond als de beste inzending.

Conform de voorwaarden van deelneming gaan wij thans over tot de publikatie van de spelregels en de bijbehorende formulieren in twee versies. Het model is op aanvrage voor onderwijsdoeleinden beschikbaar. Losse exemplaren van de spelregels en de formulieren kunnen bij de uitgever worden besteld. De prijs bedraagt voor de spelregels $f$ 5,50 per stuk. 